\title{
Bacterial and fungal flora of dust deposits in a pig building
}

W Thomson Martin, Yuanhui Zhang, Philip Willson, Timothy P Archer, Colleen Kinahan, Ernest M Barber

\begin{abstract}
Objectives-The purpose of the study was to investigate the bacterial and fungal flora of dust deposits in a newly built pig grower finisher building. Viable bacterial counts and microbial species found in a barn which had never housed pigs were compared with those in a barn housing 144 pigs.

Methods-The quantitative streak plate method was used to measure viable bacterial counts on nutrient agar or sheep blood agar. Viable bacterial counts of the dust deposits were expressed as the number of colony forming units (CFUs)/mg of dust. Gram positive cocci and Gram negative bacilli were identified by an automated system. Identifications with a confidence interval $>\mathbf{9 0} \%$ were accepted at the species level. Fungi were identified to the genus level with slide culture preparations on cereal agar.
\end{abstract}

Results-The lowest viable bacterial count $\left(4.8 \times 10^{4} / \mathrm{mg}\right.$ of dust) was found in the barn with no pigs. In the barn with pigs the highest viable bacterial count $(2.1 \times 10 \% / \mathrm{mg}$ of dust) was in dust from the top of a partition close to pig activity. Six species of bacteria or fungi were found in dust from the room with no pigs, whereas 22 different microorganisms were detected in dust from the room with pigs. With the exception of Enterobacter agglomerans no other species of the family Enterobacteriaceae was found in dust deposits in this new pig building. Twelve species of Gram positive bacteria were found in the room housing pigs.

Conclusions-The pig is not only a source but also a disperser of airborne bacteria in pig buildings. Speciation of the microbial flora in dust from the pig building suggests that many of the microorganisms were either of human or environmental origin. Nevertheless as some of these microorganisms are known opportunistic pathogens or allergens and because of the documented increased incidence of chronic respiratory symptoms in pig workers, precautions to reduce inhalation of microbial or dust particles by pig workers seem prudent.

(Occup Environ Med 1996;53:484-487)

Keywords: dust; pig building; airborne microorganisms
People who work in pig confinement buildings are known to be at risk of development of chronic respiratory symptoms. ${ }^{1}$ Reduced pulmonary function in pig workers has been correlated with the duration of exposure, the amount of dust, the concentration of airborne endotoxin from Gram negative bacilli, and the number of microorganisms in the air of the work environment. ${ }^{2}$

As part of a previously reported study on the dynamics of aerosol deposition in a pig building we investigated the viable bacterial counts and the bacterial and fungal flora of dust deposits in a newly built pig grower finisher building. ${ }^{3}$

This new building provided the opportunity to compare the microbial flora in dust deposits from a room which had never housed pigs with that of a room in the same building housing 144 pigs.

An automated identification system was used to identify $60 \%$ of the bacterial isolates to the species level. Knowledge of the ecological niche of some of these species permitted tracing of the probable origin of these bacteria in dust from the pig building.

\section{Materials and methods}

BUILDING AND ANIMALS

The building and ventilation system have been described previously. ${ }^{3}$ The conditions in this building were considered to be better than those of an average pig confinement building. Briefly this was a newly built pig grower finisher building. It housed 144 healthy pigs in 12 pens in a room measuring $14.3 \times$ $10.7 \times 3 \mathrm{~m}(47 \times 35 \times 10 \mathrm{ft})$ with a concrete floor. This represents an animal density of one animal per $3 \cdot 2 \mathrm{~m}^{3}$ of airspace. About $40 \%$ of the floor area in each pen consisted of a shallow manure gutter covered by concrete slats.

Two recirculation fans operated continuously distributing a mixture of room and fresh air through two recirculation ducts. A bank of exhaust fans was located on an outer wall.

Single space feeders in each pen were filled manually each day with dry pelleted feed.

\section{DUST SAMPLES}

Dust deposits were collected from five locations within the building. Dust was collected with a clean piece of plastic card, from natural surfaces, into small sterile plastic bags. Due to minimal amounts of dust in the room which had never housed pigs we collected a pool of dust from three sites in this room: (a) the top of 
a pen partition; (b) the top of a recirculation duct; and (c) from an exhaust fan outlet. Separate samples of dust deposits were collected from four sites in the room which had housed pigs for six weeks: (1) inside a recirculation duct; (2) an exhaust fan outlet; (3 and 4) from the top of pen partitions-one central and one by the walkway.

In the laboratory a $1 \%$ (weight/volume) suspension of each of the five dust samples was prepared in sterile physiological saline. Suspensions were prepared either immediately on receipt of the sample or after overnight refrigeration of the sample at $4^{\circ} \mathrm{C}$. Suspensions were resuspended by vortexing for 30 seconds immediately before inoculation to culture media.

\section{VIABLE BACTERIAL COUNTS}

Viable bacterial counts of the dust samples were performed on plates prepared locally from either nutrient agar or sheep blood agar base (Oxoid, Basingstoke, Hants, UK). Separate plates were inoculated with either a $1 \mu \mathrm{l}$ or $10 \mu \mathrm{l}$ loopful of dust suspension by the quantitative streak plate method. Culture plates were incubated for two days at $37^{\circ} \mathrm{C}$ in a humidified jar. Culture plates with between 20 and 250 colonies were used for measurement. Viable bacterial counts of the dust deposits were expressed as the number of colony forming units (CFUs)/mg of dust.

\section{CULTURES}

Each of the five dust suspensions was inoculated on to five different culture media. Nutrient agar and sheep blood agar (Oxoid, Basingstoke, Hants, UK) were used as nonselective media for bacteria. MacConkey's agar (Difco Laboratories, Detroit, MI, USA) was used as a selective medium for Gram negative bacilli. Fungi were isolated on Sabouraud's dextrose agar (Difco Laboratories) and Sabouraud's dextrose agar (BBL/Becton Dickinson, Cockeysville, MD, USA) with added gentamicin $(5 \mu \mathrm{g} / \mathrm{ml})$.

One set of culture plates was inoculated with $1 \mu \mathrm{l}$ of dust suspension. A second set of plates was inoculated with $10 \mu \mathrm{l}$ of suspension. Both sets of plates were streaked for isolated colonies.

Also culture plates were incubated at two different temperatures: $37^{\circ} \mathrm{C}$ and room temperature (about $22^{\circ} \mathrm{C}$ ). Cultures were incubated aerobically in jars with a humidified atmosphere. No attempt was made to isolate anaerobic bacteria.

In total 100 culture plates were used for isolation of bacteria and fungi: 5 samples $\times 5$ media $\times 2$ concentrations $\times 2$ temperatures $=100$ plates.

\section{IDENTIFICATION METHODS}

Bacterial colonies appearing after one to three days on nutrient agar, sheep blood agar, or MacConkey's agar were selected for subculture and identification. At least one colony of each visually apparantly different colony was selected for identification.

Identification methods were based on those described by Balows et al. ${ }^{4}$ Methods differed depending on the suspected organism but always included Gram stain reaction, morphology, and catalase or oxidase tests. Gram positive cocci and Gram negative bacilli were identified by the Auto Microbia system (bioMerieux Vitek, Hazelwood, MO, USA). Identifications with a confidence interval of $>90 \%$ were accepted at the species level. Corynebacteria were identified with the API coryne system (bioMerieux, St Laurent, PQ, Canada).

Fungi were identified to the genus level on the basis of colonial morphology and on microscopic morphology as viewed in slide culture preparations on cereal agar.

\section{Results}

Table 1 shows the results of viable bacterial counts. Viable bacterial counts were highest $\left(2 \cdot 1 \times 10^{6} / \mathrm{mg}\right.$ of dust $)$ in dust deposits from the top of the partition closest to pig activity. The barn with no pigs had little dust and showed the lowest viable bacterial counts $\left(4.8 \times 10^{4} / \mathrm{mg}\right.$ of dust).

Likewise, the count of Gram negative bacilli was lowest in the barn with no pigs $\left(1 \times 10^{3} / \mathrm{mg}\right.$ of dust). The number of Gram negative bacilli in dust from the recirculation duct of the room with pigs was also low ( $3 \times 10^{3} / \mathrm{mg}$ of dust) compared with a total bacterial count of $6 \times 10^{5} / \mathrm{mg}$ of dust.

Six different species of bacteria or fungi were found in dust from the room which had never housed pigs. This was in notable contrast to the room that contained pigs where we detected 22 different species of microorganism (table 2).

A single species of Gram negative bacillus (Enterobacter agglomerans (synonyms: Erwinia herbicola and Pantoea agglomerans)) was detected in the room with no pigs. This species was also the only Gram negative bacillus found in dust from the recirculation duct in the room with pigs. With the exception of Enterobacter agglomerans the absence of Enterobacteriaceae in the dust deposits is noteworthy.

Four other species of Gram negative bacilli were isolated from the room with pigs. These species were from the pen partition closest to pig activity or from the exhaust fan outlet (table 2).

Thirteen different species of Gram positive bacteria were detected in the pig building.

Table 1 Comparative viable bacterial counts in dust deposits from a pig building

\begin{tabular}{|c|c|c|}
\hline \multirow[b]{2}{*}{ Source of dust } & \multicolumn{2}{|l|}{ Viable count ${ }^{\star}$} \\
\hline & $\begin{array}{l}\text { Non-selective } \\
\text { medium } \dagger\end{array}$ & $\begin{array}{l}\text { Selective medium } \\
\text { for Gram negative } \\
\text { bacilli }\end{array}$ \\
\hline $\begin{array}{l}\text { Barn with no pigs } \\
\text { Barn with pigs: }\end{array}$ & $4.8 \times 10^{4}$ & $1 \times 10^{3}$ \\
\hline $\begin{array}{l}\text { Recirculation duct } \\
\text { Exhaust fan } \\
\text { Partition (central) } \\
\text { Partition (walkway) }\end{array}$ & $\begin{array}{l}6.0 \times 10^{5} \\
4.9 \times 10^{5} \\
2.1 \times 10^{6} \\
1.5 \times 10^{6}\end{array}$ & $\begin{array}{l}3 \times 10^{3} \\
2 \times 10^{4} \\
5 \times 10^{4} \\
4 \times 10^{4}\end{array}$ \\
\hline
\end{tabular}

${ }^{\star}$ Count/mg of dust; tsheep blood agar or nutrient agar; $\ddagger$ MacConey’s agar with crystal violet. 
Table 2 Bacteria and fungi in dust deposits from a pig building

\begin{tabular}{|c|c|c|c|c|c|}
\hline \multirow[b]{3}{*}{ Organism } & \multicolumn{5}{|l|}{ Site } \\
\hline & \multirow[b]{2}{*}{$\begin{array}{l}\text { Room } \\
\text { without } \\
\text { pigs }\end{array}$} & \multicolumn{4}{|l|}{ Room with pigs } \\
\hline & & $\begin{array}{l}\text { Recirculation } \\
\text { duct }\end{array}$ & $\begin{array}{l}\text { Exhaust } \\
\text { fan }\end{array}$ & $\begin{array}{l}\text { Pen } \\
\text { partition } \\
\text { (central) }\end{array}$ & $\begin{array}{l}\text { Pen } \\
\text { partition } \\
\text { (walkway) }\end{array}$ \\
\hline \multicolumn{6}{|l|}{ Gram positive cocci: } \\
\hline Aerococcus viridans & & & & + & + \\
\hline Enterococcus durans & & & & + & \\
\hline Micrococcus species & & + & & & + \\
\hline Staphylococcus haemolyticus & & + & + & + & \\
\hline Staphylococcus hominis & & + & + & + & \\
\hline Staphylococcus sciuri & & + & & & \\
\hline Staphylococcus simulans & & + & + & & + \\
\hline Staphylococcus species & + & + & + & + & + \\
\hline Staphylococcus warneri & + & & & & \\
\hline Streptococcus equinus & & + & + & + & \\
\hline \multicolumn{6}{|l|}{ Gram positive bacilli: } \\
\hline Bacillus species & + & + & + & & + \\
\hline Cornynebacterium species & & + & + & + & \\
\hline Cornynebacterium xerosis & & & & & + \\
\hline \multicolumn{6}{|l|}{ Gram negative bacilli: } \\
\hline Acinetobacter calcoaceticus & & & + & + & \\
\hline Enterobacter agglomerans & + & + & & 1 & \\
\hline $\begin{array}{l}\text { Non-fermentative bacillus } \\
\text { Pasteurella species }\end{array}$ & & & $\begin{array}{l}+ \\
+\end{array}$ & + & \\
\hline Vibrio species & & & & + & \\
\hline \multicolumn{6}{|l|}{ Fungi: } \\
\hline Absidia species & & & & & + \\
\hline Alternaria species & + & + & & + & + \\
\hline Cladosporium species & & & & + & \\
\hline Penicillium species & + & & & & \\
\hline $\begin{array}{l}\text { Rhizopus species } \\
\text { Scopulariopsis species }\end{array}$ & & & + & & + \\
\hline
\end{tabular}

$+=$ organism present; ${ }^{\star}$ coagulase negative.

Only two species of Gram positive cocci were found in the room with no pigs. One of these species was Staphylococcus warneri. Six species of the genus Staphylococcus including Staphylococcus sciuri were represented in dust from the pig building (table 2). However, the main pathogenic species Staphylococcus aureus and Staphylococcus hyicus were not found.

Six genera of fungi were detected in dust deposits from the building. The genus Alternaria was found in dust samples from four sites (table 2).

\section{Discussion}

Donham et al reported total bacterial counts of $1.4 \times 10^{3} / \mathrm{mg}$ of pooled settled dust from three pig confinement buildings in Iowa, United States. ${ }^{5}$ The locations of the dust within the buildings were not specified in the Iowa study and only one medium (cycloheximide nutrient agar) was used. This may account in part for the lower counts in the Iowa study compared with our total bacterial counts of $4.9 \times 10^{5}-2.1 \times 10^{6} / \mathrm{mg}$ of dust depending on the location in the barn with pigs. The predominance of $\mathrm{Gram}$ positive over Gram negative bacteria is evident, however, in both studies.

As might be expected dust deposits closest to pig activity showed the highest concentrations of bacteria and also the greatest variety of microorganisms. Precautions by pig workers against inhalation of airborne bacteria would therefore seem to be most critical when actually working inside pig pens close to pig activity.

As 11 species of microorganism were found in dust deposits in the exhaust fan outlet, and as the exhaust air is representative of the room air in general, it would also seem prudent for workers to take precautions such as wearing protective masks whenever they are in the pig building.

The concentration of endotoxin in the air of pig buildings is recognised as a particular hazard to pig workers but endotoxic activity of Gram negative bacteria is known to vary considerably. Thus endotoxin from Escherichia coli is recognised as one of the most potent. ${ }^{6}$ The absence of this faecal organism from the dust deposits investigated - even dust from the pen partition a few feet above pig activity-suggests that the animal density and design of this building was particularly appropriate or that Gram negative bacilli are less likely to become highly airborne or survive drying than Gram positive bacteria. The probability of these interpretations is strengthened by the finding of 13 species of Gram positive bacteria in the dust deposits of the building compared with only five Gram negative species (table 2). These findings are in agreement with those of Wiegand and Hartung ${ }^{7}$ who found Gram positive bacteria more frequently than Gram negative bacteria in the air of a cattle clinic.

The relatively low count of Gram negative bacilli compared with the total bacterial count found in the recirculation duct $2.4 \mathrm{~m}$ above the floor also suggests that Gram negative bacilli are less airborne than Gram positive bacteria (table 1). Furthermore, Enterobacter agglomerans was the only Gram negative species found in dust from the recirculation duct. This species is most likely non-human and non-porcine in origin. ${ }^{8}$

The main source of several organisms detected in the building is not likely to have been the pigs. Acinetobacter is almost always present in soil and water. ${ }^{9}$ Acinetobacter may also be found on human skin especially on the skin of perspiring men. ${ }^{10}$ Likewise, Enterobacter agglomerans although it may be found in humans is more commonly found in association with plants, water, soil, or foodstuffs. ${ }^{8}$

Both of these Gram negative bacilli are essentially saprophytic but both may be opportunistic pathogens in humans. Acinetobacter calcoaceticus may cause tracheobronchitis and pneumonia especially in people whose host defenses are reduced by other causes. ${ }^{9}$ Both Acinetobacter calcoaceticus and Enterobacter agglomerans contain lipopolysaccharide in their cell walls but little is known about their endotoxigenic potential.

Staphylococcus warmeri was found in the room with no pigs. The most common known source for this species is human skin. ${ }^{11}$

All six of the fungal genera isolated were most likely of non-porcine or non-human origin. ${ }^{12}$ However, at least two of these fungi (Alternaria and Cladosporium) are well recognised fungal allergens. ${ }^{13}$

A particularly noteworthy feature of this study was the variety of Gram positive cocci detected in dust deposits. Staphylococcus haemolyticus, Staphylococcus hominis, Staphylococcus simulans, and Staphylococcus warneri are all known to occur on human skin although their presence on the skin of other animals has not been adequately assessed. ${ }^{11}$

Of special interest was the presence of 
Staphylococcus sciuri (formerly Staphylococcus group III) in dust from the recirculation duct. This isolate was most likely of porcine origin although it is not possible to rule out a rodent origin. ${ }^{14}{ }^{15}$ Staphylococcus sciuri is known to be significantly more proteolytic than human strains of coagulase negative staphylococci. ${ }^{14}$ If this species was of porcine origin then finding it inside the recirculation duct suggests it is readily airborne. Whether inhalation of Staphylococcus sciuri or other staphylococci of porcine origin present a particular hazard to pig workers is not known.

Most of the bacterial species and the spores of the fungal species isolated from the pig building are of a size $(1-5 \mu \mathrm{m})$ which may be inhaled into the bronchi and alveoli of the human lung. Although most of the microorganisms we detected fall into the categories of normal human or animal flora or environmental saprophytes, some are known opportunistic pathogens or allergens. Because of the documented increased incidence of chronic respiratory symptoms in pig producers it seems appropriate to take all reasonable precautions to reduce inhalation of these microorganisms and other dust particles by workers.

Although some authors ${ }^{7}$ have emphasised the importance of animals as a source rather than disperser of airborne bacteria in animal houses, our study which speciated isolates to a greater extent than many previous studies suggests that human workers and the environment also represent significant sources of microorganisms in pig buildings.

Occupational health professionals have tended to neglect the health and safety issues of agricultural industries in comparison with other industries. ${ }^{16}$ The predominance of the family farm in the agricultural industries has made it difficult to focus attention on the epidemiology of occupational related disease in the farming industry. For example, the National Pork Producers Council (NPPC) in the United States has only very recently (1995) formed a task force to emphasise health and safety concerns of pork production systems. ${ }^{17}$ These concerns include respiratory diseases among pork producers. It is known that pork producers are at risk of atypical farmer's lung (pulmonary mycotoxicosis). ${ }^{16}$ Hazards to health from inhaled biologically active dusts may be increasing among farm workers as the number of animal confinement buildings increases on farms. ${ }^{16}$ Our study emphasises that pigs in barns are efficient dispersers of microorganisms from several different sources. Bacteria and fungi are just two components of dust in animal confinement buildings. Occupational health physicians need to emphasise the health hazards for farm workers of long term inhalation of biologically active dust. Control of the amount of dust in animal confinement buildings and the developement and use of effective respiratory protective equipment for farm workers remains an area of concern.

Financial support for this project was provided by the National Science and Engineering Research Council of Canada. Technical support was provided by the staff of the Prairie Swine Centre, Saskatoon, SK, Canada.

1 Zejda JE, Hurst TS, Rhodes CS, Barber EM, McDuffie $\mathrm{HH}$, Dosman JA. Respiratory health of swine producers: focus on young workers. Chest 1993;103:702-9.

2 Donham K, Haglind P, Peterson Y, Rylander R, Belin L. Environmental and health studies of farm workers in Swedish swine confinement buildings. Br f Ind Med 1989;46:31-7.

3 Zhang Y, Barber EM, Martin WT, Willson PJ. Dynamics of aerosol deposition in a swine building: a pilot study. American Society of Heating, Refrigeration, and Air Conditioning Engineers: Transactions of 1994;100:906-12.

4 Balows A, Hausler Jr WJ, Herrmann KL, Isenberg HD Shadomy HJ. Manual of clinical microbiology, 5th ed. Washington: American Society for Microbiology 1991.

5 Donham KJ, Scallon LJ, Popendorf W, Treuhaft MW, Roberts RC. Characterization of dusts collected from swine confinement buildings. Am Ind Hyg Assoc $\mathcal{F}$ 1986; 47:404-10.

6 Hurley JC. Endotoxemia: methods of detection and clinical correlates. Clin Microbiol Rev 1995;8:268-92.

7 Wiegand B. Hartung J. Bacterial contamination of air and floor surfaces in an animal house of a cattle clinic. IVth International Livestock Environmental Symposium. St Joseph, Missouri: American Society of Agricultural Engineers, 1993:643-9.

8 Richard C. Genus VI. Enterobacter. In: Krieg NR, Holt JG, eds. Bergey's manual of systematic bacteriology. Vol 1 . Baltimore: Williams and Wilkins, 1984:465-9.

9 Allen DM, Hartman BJ. Acinetobacter species. In: Mandell GL, Bennett JE, Dolin R, eds. Principles and practice of infectious diseases, 4th ed. New York: Churchill Livingstone 1995: 2009-13.

10 Roth RR, James WD. Microbial ecology of the skin. Ann Rev Microbiol 1988;42:441-64.

11 Kloos WE, Schleifer KH. Genus IV. Staphylococcus. In: Sneath PHA, Mair NS, Sharpe ME, Holt JG, eds. Bergey's manual of systematic bacteriology. Vol 2 . Bergey's manual of systematic bacteriology.

12 Rippon JW. Medical mycology: the pathogenic fungi and the pathogenic actinomycetes, 3rd ed. Philadelphia: WB
(a) pathogenic actino

13 Horner WE, Helbling A, Salvaggio JE, Lehrer SB. Fungal allergens. Clin Microbiol Rev 1995;8:161-79.

14 Smith RF, Bettge CL. Comparative characteristics of human and porcine staphylococci and their differentiation in burn xenografting procedures. Appl Microbiol 1972;24:929-32.

15 Kloos WE, Schleifer KH, Smith RF. Characterization of Staphylococcus sciuri sp. nov. and its subspecies. Int $\mathcal{f}$ Syst Bacteriol 1976;26:22-37.

16 Popendorf W, Donham KJ, Easton DN, Silk J. A synopsis of agricultural respiratory hazards. Am Ind Hyg Assoc $\mathcal{F}$ 1985;46:154-61.

17 National Pork Producers Council (US): NPPC worker health and safety task force is formed. Swine Health Production 1995;3:213. 